\title{
Three-Dimensional Works Designed for Schools Without Studios: A Multiple-Case Study
}

\author{
Berna COŞKUN ONAN ${ }^{1} \&$ Mert ÜNLÜSOY ${ }^{2}$ \\ ${ }^{1} \mathrm{PhD}$. Fine Arts Education Department, Faculty of Education, Bursa Uludağ University, Bursa, Turkey \\ ${ }^{2}$ Master of Fine Arts Education, Bursa, Turkey \\ Correspondence: Berna COŞKUN ONAN, PhD. Faculty of Education, Bursa Uludağ University, Bursa, Turkey. \\ E-mail: onanberna@uludag.edu.tr
}

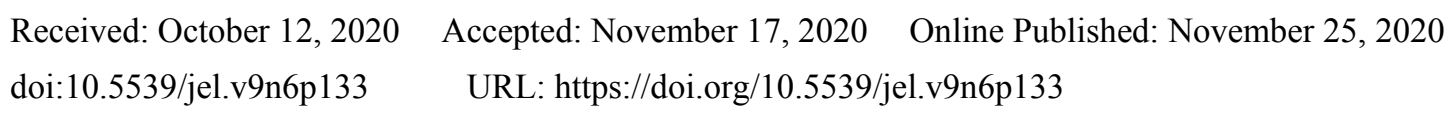

\begin{abstract}
Based on the learning outcomes, values, skills/proficiency and job safety for grades 6,7 and 8 from the 2017 Visual Arts Course Curriculum (MEB, 2017), outcomes related to three-dimensional work have been associated with care, love, responsibility and inquiry and activities "My Money", "Abstract Sculpture" and "Talking Emojis" have been planned. They have been completed with visually rich presentations and step by step implementation phases and presented to the subject teachers intended for practices. In the data collection process, the activities were observed by the researcher, audio and video recording made and right after the activities interviews with the students and teachers were made and student work was collected to examine documentation. Data obtained during the data collection process have been analyzed with thematic analysis method and taking into consideration the basic characteristic of multiple case study and the themes obtained have been evaluated with the theme titles; "Connections", "Internalization" and "Realization". Among the outcomes of the results of the research are the facts that the bases of skill/proficiency, value and job safety are important at activity planning and that rich presentations and step by step applications can transfer the relevant outcomes of the students into behavior. It is also attention-grabbing that students, who gain the values of respect, love and care for their environment through three-dimensional work, can transfer mathematical, digital, social skills and those related to citizenship to their lives.
\end{abstract}

Keywords: skill, value, job safety, outcome, sculpture

\section{Introduction}

\subsection{Three-Dimensional Works in Education}

Arnheim (1969) approaches art as one of the significant intentions arising from the need of man to understand $\mathrm{him} / \mathrm{herself}$ and the world s/he lives in. He states that the general aims of art are also connected to this basic cognitive function and thus, art draws near the meaning and consequence of science (p. 294). From the second half of 19th century on, interest in art in large masses of communities in the presiding countries in the industrialization process has increased (Efland, 2002). Chapman (1994, p. 2) points out that art education has three main aims, which are producing art, observing the artwork and living with art. Artistic production contains learning how to create original art work and expressing visual experiences. Thus, the person learns how and why the artists of the past and today create and produce. Observation of art requires learning to see. One of the objectives of the visual arts course is to become aware of people of different cultures and to help establish connections between life and art. If, the three-dimensional work as a subject that includes the student with an active role, listening, seeing, thinking and applying at the teaching and learning activities in the visual arts course are not implemented suitably, the targeted outcomes will be left out. The reason is that research has put forward that during classes students should do more than just listening (Arslan, 2000). If this property of three-dimensional work that is remarkably close to active learning is not fully benefited from, the learning activities will fall short. Children perceive objects within three dimensions in the rate of their recognition. They can carry out figuration work with their emotions, thoughts and images and develop their design skills. Besides kneading materials, among the most effective and practical three-dimensional work are different shapes and compositions taking the coupling of shapes based on various geometrical shapes (cube, rectangle, pyramid, cylinder etc.). Many art educators mention the significance of three-dimensional work in child development and 
art education (Barnes, 1993; Canikoğlu, 2016; Gençaydın, 1990; Kenavlı, 2017; Lancaster, 2002; Manners, 1997; San, 2003; Sharples, 1985). According to these research, three-dimensional work provides that children;

- Observe, comprehend, and present three-dimensional work and their connections with their environment,

- Comprehend the general features of materials such as wood, paper, cardboard, rope, plastic, clay, stone etc. by experiencing carving, kneading, adding-extracting and cutting,

- Developing manual skills,

- Using the three-dimensional work materials safely,

- Thinking within three-dimensional terminology,

- Developing their problem-solving skills while solving problems encountered at design and construction stages,

Understanding, respecting, and appreciating the sculptors, architects and ceramic artists creating three-dimensional work and their works.

The role and significance of touch and contact in learning is frequently emphasized in literature (Manners, 1997). Adults as much as children need to touch an object in order to understand it. Thus, they try to learn the attribution of the object. Considering these, three-dimensional work provides the first-hand opportunity for the child, which is the most important characteristic of art education (Demir, 2009; Küpeli, 2014; Canikoğlu, 2016). Seeing is not sufficient for children. The child feels the mass while teaching the three-dimensional concept and this provides firsthand learning. three-dimensional work separates three-dimensional from two-dimensional with the attempt to create a three-dimensional effect on the painting.

\subsection{The Gap in Three-Dimensional Works Planned as to MSVAC and TQF}

Education is a long process that includes the acquisition of skills, talents, attitudes, aesthetic sensitivity, values and positive behavior, especially cultural values. The permanence of the change occurring in this process is accepted as one of the main determinants of development. While improving the living standards of the individuals, the skills gained make a significant contribution to the international competition capacities and democratic development of the society, in which they grow up. Quality education is only possible with programs taking the individual differences into consideration. At the identification of basic skills covered by the outcomes in the curricula in Turkey the Turkish Qualifications Framework (TQF, 2015) [TYÇ] is taken as the basis. Turkish Qualifications Framework (TQF) has been designed in alignment with the European Qualifications Framework (EQF, 2017). It is the national qualifications framework that demonstrates all qualifications bases gained with vocational, general, and academic education curricula and other learning methods, including primary, secondary and higher education. In TQF there are eight key qualifications that are expected to be gained by each individual within the scope of lifelong learning (MEB, 2017). In the 2017 curriculum these are communication in mother tongue, communication in foreign languages, mathematical qualifications and science/technology qualifications, digital qualification, learning how to learn, social and citizenship qualifications, initiative and entrepreneurship perception, cultural awareness, and expression. The activities within the scope of this research have been planned to take three areas of qualifications as basis, considered to be aligned with these outcomes (mathematical qualifications and science/technology qualifications, digital qualification and social and citizenship qualifications). The studies carried out in the United States in 1920s with the title character education are currently called values education. Studies related to values education were published after mid-1970s. As the significance attached to social and moral values decreased in $1990 \mathrm{~s}$, values for individual adaptation came to the forefront. Social problems that arose after this period brought values and moral education forward again. When faced with these negative developments, families, educators, and social leaders started to emphasize moral and values education in schools again (Demircioğlu \& Tokdemir, 2008, p. 73). Currently values education is implemented with the transfer of values placed within the subjects in the curriculum. It is considered that not teaching the values as outcomes and leaving them to the initiative of teachers in the curriculum will affect consistency in education negatively. Within the scope of this research, values of respect, care, responsibility and inquiry have been taken as the basis.

Researchers advocate that three-dimensional work attracts the attention and interest of children more than painting work (May, 1987; Hathaway, 1984; Sharples, 1985). Several British scholars mention the issue that in British schools (primary and middle schools) three-dimensional work is the most neglected and at the same time the less frequently implemented type of art work (Sharples, 1985; Lancaster, 2002; Thistlewood, 1991; Barnes, 1993; Manners, 1997). Researchers state that the reasons for this are the insufficient knowledge, experience, and lack of self-confidence of teachers and that such work is difficult to organize. A look from Turkey tells us about 
the reasons for infrequent implementation of three-dimensional work that they are insufficient class time and lack of studios (Canikoğlu, 2016; Gel, 1993; İnan, 2018; Karagöl, 2016; Kenavlı, 2017; Özdemir, 2009; Sayg1, 2015).

Three-dimensional work (sculptures, relief, ceramics, models and object installations) that cover figuration techniques, where several outcomes, skills and values can be used, is in the Middle School Visual Arts Curriculum (MSVAC) (MEB, 2017) in Turkey; however, it cannot be realized effectively and as necessary due to the physical inadequacies of schools. The research is of importance as it presents the three-dimensional work in the 2017 MSVAC as planned activities. These activities can be applied in the classroom at levels 6 (G.6), 7. (G.7.) and 8 (G.8), taking into consideration the issues of outcomes, values, skills and job safety. It also puts forward effective suggestions for the curriculum, teachers and researchers.

\subsection{Aim of the Research and Research Questions}

The aim of the research is to put forward how three-dimensional work in the Visual Arts Curriculum (MEB, 2017) can be implemented in the classroom from the perspectives of skill/qualification, values and job safety and also to set forth the roles of experiencers. Within this aim, answers for a question has been sought (1) How can three-dimensional works for the Middle School Visual Arts Curriculum (MSVAC) and for implementation in the classroom be planned? 2) In the planned activities how can precautions for a) Content, b) Outcome, c) Values, d) Skill/qualification, e) Job safety specified?

\section{Method}

Moving from this problematic situation encountered frequently in literature, a qualitative research has been planned, which aims to describe how the three-dimensional work structured within the framework of the specified outcomes, skills, values and job safety rules can be planned. Qualitative research is a research approach that aims to obtain in-depth knowledge about a subject, situation, or approach with the interpretations of the experiencers (Creswell, 2013, p. 45).

\subsection{Research Design}

In this research, as a design providing the expression of specific situation or situations clearly and that also provides the description with various data sources, multiple case study basic principles have been preferred. According to Yin (2009), while the researcher is planning the multiple-case design, s/he researches the situation specified under different conditions and following the same procedures. In this research, for the specified aim, activities for each grade level (6,7 and 8. grades) have been planned with relevant outcomes, values, and skills and in line with job safety rules. These activities have been implemented in three different schools that have no studios and where, in this respect, the visual arts lessons are carried out under similar conditions. The problem of the research and details of the activities that were planned related to the research questions and realized and how they took part in the data collection process have been presented below with details and tables.

My Money Activity. The student uses carving, assemblage, or modeling techniques to form three-dimensional work as though the Figure 1. (Outcome no. G.6. 1.7, 6th grade, MSVAC)

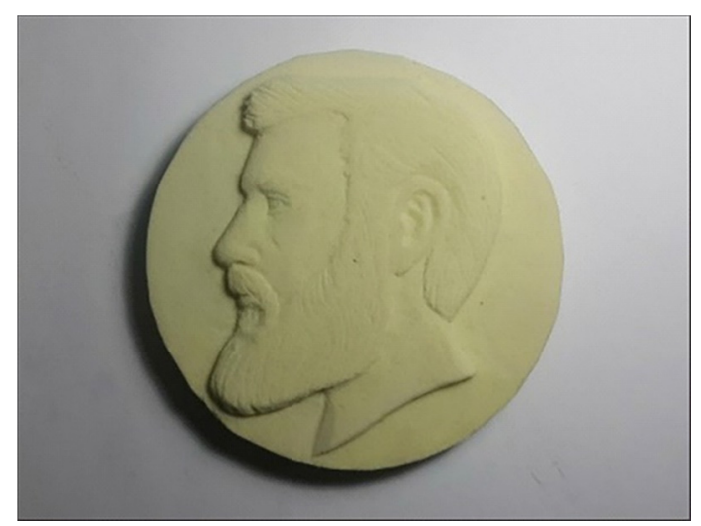

Figure 1. Practice sample made with foam for the My Money Activity

In this activity, students are reminded of art elements and design principles in Anatolian Civilizations and they are 
expected to apply the money, which is of great importance in Lydian civilization, using relief technique over foam. It is aimed that they reflect their emotions and ideas on their work during this study. Analysis and evaluation of how the past civilizations and artists used forms, materials and symbols in their works are emphasized. The activity may form a foundation for the individual to understand his/her cultural fully and for an open attitude for the diversity of cultural description with respect. The positive attitude also includes development of artistic and aesthetic capacity and creativity through personal expression and participation in cultural life. At the same time, it is also aimed that students gain mathematical skills with this activity. All data on the activity have been presented in the tables and findings with the acronym MM in the text.

Abstract Sculpture Activity. The student uses waste material to create three-dimensional work as though the Figure 2. (Outcome no. G.7.1.7, 7th grade, MSVAC)

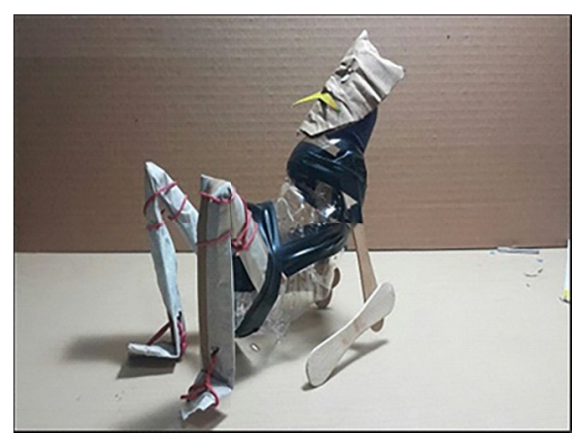

Figure 2. Practice sample made with waste materials for the Abstract Sculpture Activity

With this activity, research of the creative process, its analysis and discovery in the artwork are emphasized. It is provided that students use traditional and contemporary art materials in line with art elements and design principles to design. It is emphasized that while students evaluate themes, topics, and symbols in artworks, they use inquiry skills and develop visual art language. It is aimed that researching the meaning and value of art is encouraged. During this study, recycling will be emphasized, and it is aimed that the values of care and responsibility will be stressed. The activity involves personal, interpersonal cultural and intercultural efficiency and also all forms of the behavior for individuals to participate in social and business life. In addition, it includes acquisition of various behaviors to provide to solve divergences at necessary situations. Individuals with this efficiency should be interested in socio-economic development and intercultural interaction, should value diversity, respect others and be prepared to cope with prejudices and ready for reconciliation. All data on the activity have been presented in the tables and findings with the acronym AS in the text.

Talking Emojis Activity. The student uses different techniques and materials to make a three-dimensional work as though the Figure 3. (Outcome no. G.8.1.8, 8th grade, MSVAC)

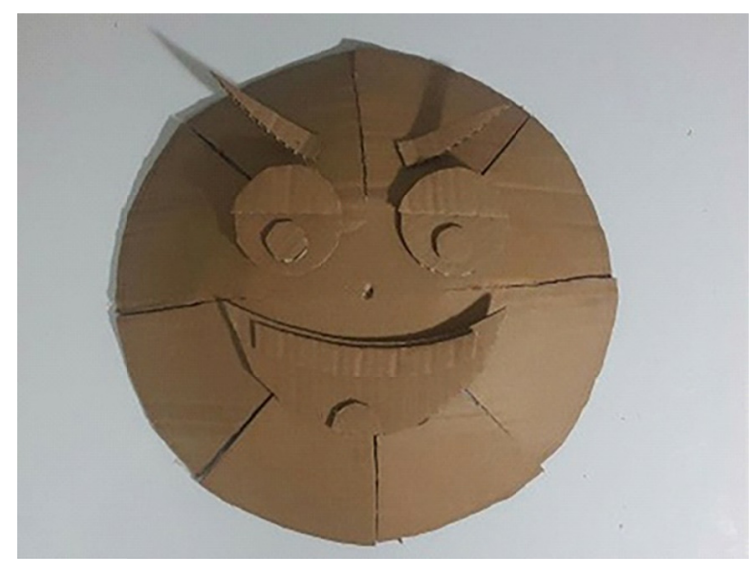

Figure 3. Practice sample made with paper for Activity Talking Emojis 
This activity focuses on the interiorization of students' prior knowledge, skills and experiences. It is provided that students use different techniques together while creating their visual art works. In order for the students to develop their judgments on artwork, it is aimed that inquiry is carried out on the aim, meaning and value of art. It is also an objective that students gain digital skills. Digital skill involves using information society technologies safely and critically for daily life and communication. The said qualification is supported by the basic skills of accessing information and evaluating it within information technology, using computers to save, produce, present and exchange information and also participation and communication in networks through the internet. All data on the activity have been presented in the tables and findings with the acronym TE in the text.

\subsection{Sampling Procedures and Participants}

The sampling of the research has been specified according to homogenous sampling specification strategy as three teachers from schools with no art studios and study groups with similar features from three schools in Nilüfer, Osmangazi and Yıldırım districts of Bursa city. The homogenous groups are those groups that are formed by people with similar backgrounds and with the same experience (Patton, 2018, p. 235). Accordingly, the characteristic that makes three different schools homogenous is that they do not have art studios. The research has been carried out in the selected schools of Bursa city central districts, Yahya Kemal Beyatlı Middle School (Yıldırım) (A School), Meliha Cemal Bağcı Middle School (Osmangazi) (B School) and Ali Durmaz Middle School (Nilüfer) (C School). The participants of the research are three Visual Arts teachers of grades 6, 7 and 8 and five students (with code names) from each grade level, 6, 7 and 8 who attend the activities consistently from each school.

\subsection{Data Collection Process}

As the research is a multiple-case study, it is significant that the data forming at the situations is collected regularly and clearly. Taking into consideration the typical structure of multiple-case design, the data collection process was conducted at three different schools concurrently. In the data collection process, the tools have been used in common and concurrently in order to be able to provide action integrity and to increase reliability.

As the research is a case study, in the implementation stage of the three-dimensional activities in the classroom, semi-structured class observation form (SSCOF), including six items about preparing, instructing, interaction etc. in the classroom, has been used. This form is in line with weighted data collection methods (Yıldırım \& Şimşek, 2013, p. 199). Due to the practical structure of the research, all artistic products and lesson materials that the students created were examined with data collection technique. According to Merriam (2018, p. 132) these documents are classified as visual documents, physical materials/artifacts and documents produced by the researcher. In this study among the documents produced by the researchers are Peer Evaluation Form (PEF) and Self-Evaluation Form (SEF) including (10-15) items (i.) about self's and his/her peers' experiences in the pre-process, meanwhile and after process. Peer evaluation is a process, in which the work of the individual is evaluated by his/her classmates within specific criterias ( 10 items) and according to their perspectives. In the data collection process of the process, in order to have more depth in the data obtained by video recording, document analysis and observation, interviews have been held with the practitioner teacher (SSIF) and students using a semi-structured interview form (SSIF) including questions (q.) such as "How did you relate your artwork with yourself?", "How did you specify your theme in your process?. Semi-structured interviews are one of the data collection techniques used in qualitative research methodologies frequently, which provides interaction between the researcher and participant (Glesne, 2012, p. 140, 182). The findings on interviews have been presented with q. shortly in the results. In Table 1 below detailed information about the data collection process and the data collection tools used has been presented.

Table 1. Data collection process and the tools used

\begin{tabular}{|c|c|c|c|c|}
\hline Activity-Grade Level & $\begin{array}{l}\text { Multiple-case } \\
\text { Schools }\end{array}$ & $\begin{array}{l}\text { Data collection } \\
\text { technique }\end{array}$ & $\begin{array}{l}\text { Participants } \\
\text { applicable }\end{array}$ & Data collection tools- Form details \\
\hline $\begin{array}{l}\text { My Money } \\
(\mathrm{MM}) 6^{\text {th }} \text { Grade }\end{array}$ & $\mathrm{A}, \mathrm{B}, \mathrm{C}$ & Observation & Visual Arts Class & SSCOF 6 items (MM), (AS), (TE) \\
\hline / & $\mathrm{A}, \mathrm{B}, \mathrm{C}$ & Interview & 3 Teachers & Teacher SSIF \\
\hline Abstract Sculpture & & & 15 students & 11 questions (MM), (AS), (TE) \\
\hline (AS) $7^{\text {th }}$ Grade & & & & Student SSIF \\
\hline & & & & 21 questions (MM), 24 questions (AS), 25 \\
\hline $\begin{array}{l}\text { Talking Emojis } \\
\text { (TE) } 8^{\text {th }} \text { grade }\end{array}$ & $\mathrm{A}, \mathrm{B}, \mathrm{C}$ & $\begin{array}{l}\text { Document } \\
\text { examination }\end{array}$ & $\begin{array}{l}3 \text { Teachers } \\
15 \text { students }\end{array}$ & $\begin{array}{l}\text { questions (TE) } \\
\text { PEF } 10 \text { items (MM), (AS), (TE) } \\
\text { SEF } 15 \text { items (MM), (AS), (TE) }\end{array}$ \\
\hline
\end{tabular}




\subsection{Data Analysis Process}

Data collected during the data collection process of the research were analyzed with an inductive and thematic approach, focusing on the similarities and differences of the schools in different districts. While doing this, Stake's (1995) categorical aggregation and Yin's (2009) cross state analysis methods were taken into consideration that are used in multiple-case studies. In the study, to put forward the commonalities in three different schools, only the PEF and SEF forms were analyzed in percentage value and in the findings, they have been used in this form as supporting data and presented via i. shortly in the results.

\subsection{Reliability and Validity Studies}

In order to increase the validity and reliability of the research, the context and description of the research were made clearly, and in the findings detailed depictions, visuals and direct quotations were given with references to the data set (Miles \& Huberman, 2019). However, in the data collection process that was conducted with teachers and students from three different schools, triangulation could also be mentioned. Here, it was attempted to increase reliability and validity through provision of variety in data collection techniques (Patton, 2018, p. 556).

\section{Results}

Findings consist of three themes as "Connections", "Internalization", and "Realization". These themes are categorized by considering the basic characteristic of the multiple-case study, which is the design of the research, and in reporting the themes, three different schools are simultaneously evaluated in a common context and are shown collectively in Table 2 below. While reporting the research, the most comprehensive categories have been chosen and explained with the codes.

Table 2. Themes and categories obtained at the analysis

\begin{tabular}{llll}
\hline Themes & Connections & Internalization & Realization \\
\hline Categories & Communication Connections & Win Recognition & Design Process \\
& Art Areas & Subjective Preferences & Materials Selection \\
& Through Art & Social Values & Process for Adding Dimension \\
& Association of Life and Art & Personality Development & Providing Safe Conditions \\
& In-class Interactions & Artistic Sensitivity & Problems Experienced \\
& Educational Common Ground & & Suggestions to Improve the Activity \\
\hline
\end{tabular}

\subsection{Connections}

The connections theme involves various theoretical, practical or life-oriented connections that were established or were foreseen to be established, which rose during the educational period.

\subsubsection{Through Art}

Under this category the connections students make with art elements and design principles through three-dimensional work in the instructional process. Under this category are "having objects gain new meanings", "transforming fantasies to objects", "transmission of psychomotor skills", "orienting collective consciousness", "realization of social change", "benefiting from the psychological effect of color", "connecting with knowledge of other areas", "skill of using and managing knowledge", "using the existing knowledge", "wish to get to know cultures", "perceiving the sustainability of culture" "making a connection between culture and history". An example is: As a result of students implementing the abstract sculpture activity with the code "transmission of psychomotor skills" in classroom environment shows that they have realized that all daily life materials can be transformed into artwork (SSCOF, (AS), i.2, 3, 5). As an example for the above the following student answers could be given: "I used my knowledge of shaping, cutting, gluing, drilling knowledge I learned previously." (Şeyda, A (AS), student and Aykut from school C: "What I could do previously are gluing the tape and keeping the balance even.” (Aykut, C (AS), student SSIF, q. 11).

\subsection{Internalization}

The theme internalization involves the knowledge of the students they acquired as a result of the situations they encountered during the instructional process and their personal preferences.

\subsubsection{Personality Development}

With the codes under this category, explanations about individual students' personality development through three-dimensional work have been put together. The codes under this category are "developing artistic sensitivity", 
"enjoying differences", "developing self-confidence", "learning the significance and value of art", "acquisition of social values", "doing instead of throwing away", "discovery of creativity", "display as a motivational tool", "gaining recycling awareness", "the liberating aspect of embodying", "adaptation to change", "critical thinking", "solution-oriented personal development", "effort to overcome prejudices", "solving problems in practices", "development of personal expression", "getting to know one's own culture". The code "developing self-confidence" specified among these shows that as a result of the implementation of the activities "Talking Emojis" and "Abstract Sculpture" in classroom environment, students developed self-confidence. Examples for this situation are as follows: Aliye: "Shaping my form freely brings me self-confidence." (Aliye, A, (AS), student SSIF, q.5) and Betül: "I have observed at myself that it gives me a passion for doing better." (Betül, A, (AS), student SSIF, q.24). Emel teacher from school B: "Self-confidence and hard work could also be approached." (Emel, B, (AS), teacher SSIF, q.3). These words put forward the significance of the value of self-confidence. Also, the 64\% "Yes" answer of the students for item 14 of the "Self-Evaluation Form" for the activity "Talking Emojis" that was implemented commonly at the three schools, namely, "I was happy to transfer what I pictured in my mind on the three-dimensional work" supports this code (A, B, C, (TE) SEF, i.14).

\subsection{Realization}

The theme realization involves the life experiences during the instructional process.

\subsubsection{Process for Adding Dimension}

This category explains the implementation stages of student design during the instructional process. The codes under this category are "embodying based on material", "gaining experience", "feeling of producing together", "realization of the outcome", "giving feedback within the process", "transforming the two-dimensional image to three-dimensional", "development of psychomotor skills", "approaching dimensioning with prejudice", "contribution to problem solving skill", "interference of the teacher in the implementation stage", "psychomotor skills", "learning through trial and error", the significance of instructional material", "dimensioning knowledge", "dimensional work experience", "multiple-skills developing", "cognitive outcomes of dimensional work", adaptation in practice" and "contribution of dimensional work to skills". The code "Contribution of Dimensional Work to Skills" emphasizes the fact that during the implementation of the activity "My money" in classroom environment students gained various skills. The following student comments support this code: Kaniye from school B: "I have developed my mathematical and logical skills." (Kaniye, B, (MM), student SSIF, q.6) and Vahide from school C: It developed my imaginative power." (Vahide, C, (MM), student SSIF, q.6). Also, the "Yes" answer at $84 \%$ for item 14 in the "Self-Evaluation Form", namely, "During this activity I have realized that my creativity and mathematical skills improved." supports this code (A, B, C, (MM) SEF, i.14).

\section{Discussion and Suggestions}

As the research design is multiple-case study, the section for discussion has been structured in such a way as to explain the commonalities of the obtained results of the investigated situations at the three schools by the help of codes. Thus, the work has been consolidated using the teacher and student remarks and comments among the research results and the common codes that arose similarly at two (AB, BC, AC) or three schools $(\mathrm{A}, \mathrm{B}, \mathrm{C})$. The results ensued within the scope of the research consist of 3 themes, 17 categories and 153 codes under the titles "Connections", "Internalization" and "Realization". With this approach, the discussion has been conducted for three-dimensional work to be planned at schools with no studios and related to literature and suggestions have been put forward in each section.

\subsection{Outcomes}

Within the scope of the research, the Learning Areas of Visual Communication and Figuration, Cultural Heritage and Art Critique and Aesthetic Learning from the 2017 curriculum for grades 6, 7 and 8 have been examined and content appropriate for these levels have been created and the outcomes in classroom environment have been evaluated. The results of this study that was prepared by combining these three learning areas and through the activities implemented indicate that there is outcome-focused data in each theme. It is considered that the learning outcomes in the curriculum will reflect in student behavior through comprehensive activities (MM), (AS), (TE) that will be prepared for three-dimensional work and taking into consideration the physical conditions and number of students in the classroom. This opinion shares similarities with Çapar's (2006) and Canikoğlu's (2016) results that emphasize that with activities that are planned correctly students show interest in three-dimensional work and enjoy them. At the observations made during the implementation of the activities it has been observed that students follow the details in the activity presentations prepared by the researcher and conduct the step by step stage correctly along the instructions (MM), (AS), (TE) DSSIF, i.1, 2). These results align with Çapar's (2006) and İnan's (2018) results in his study that there are positive effects of the theoretical and visual presentations made by 
the researcher during the activities.

In this research for grade 6 students the learning outcomes from the learning area Visual Communication and Figuration "G.6.1.7. The student uses carving, assemblage or modeling techniques to make three-dimensional work." and the learning outcome from the learning area Cultural Heritage "G.6.2.4 the student examines work from Anatolian civilizations through museums." have been approached jointly and content appropriate for classroom environment has been developed. These connections made between the activity "My Money" and learning areas are closely related to the social and cognitive connections established for the reflections of learning outcomes to student behavior in situations, where there is no art studio. The cognitive outcomes of the research: concept outcome (A, C), enjoying the process of abstraction (C, B), impact of differences on creativity (A, C), change of perception of art object (A, B) demonstrate that various cognitive outcomes can be obtained through three-dimensional activities in schools with no studios. Another example is the code using the existing knowledge (A, B) According to these, in both schools the students transfer the knowledge they have acquired from the visual arts course or from other subjects. These results of the research are in alignment with İnci's (2012) work, in which the results are that at the objective reality step the objects are perceived with three dimensions as in reality and the three-dimensional figuration work has an enriching quality for the learning outcomes of the lesson for students. In addition, in his study Akıncı (2009) has emphasized the significance of three-dimensional work in education as a requirement of modern life. He states that research for materials and techniques, observation of their impact and specification of problems are important when the student approaches multifaceted thinking and perception models. Also, these are important to reach the educational aims, to search for solutions and specify strategies. In his study, Karaoğlu (2004) reached the result that when the learning outcomes of two- and three-dimensional work were compared, distinct differences in favor of three-dimensional work were identified. In their studies Çapar (2006), Karatop (2005) and Akınc1 (2009) observed that during the preparation of the activities by the Visual Arts teacher, students were much more successful when the presentations were enriched. Akınc1 (2009) emphasizes the fact that materials enrichment is one of the topics that should be particularly taken into consideration by the subject teachers in order to achieve more learning outcomes through this subject.

From the Visual Communication and Figuration learning area for 7th grades the learning outcomes "G.7.1.7. The student carries out three-dimensional using waste material" and for 8th grades "G.8.1.8. The student carries out three-dimensional work using different techniques and materials together" have been selected from among the activities that dominate the research. Specification of content appropriate for the level during the planning of the activities has provided that many learning outcomes could be achieved. The multiple-cases that put forward these learning outcomes are those that were towards appreciation demonstrating that students internalized learning during implementation. In all three schools the students regarded their work that was produced at the activities was worth for display (A, B, C); they remarked that it was displayable at the museum $(\mathrm{A}, \mathrm{C})$; they mentioned the pleasure of new knowledge $(B, C)$ aand that they felt themselves valuable $(B, C)$. These codes and particularly their adoption of variety in color selection $(\mathrm{A}, \mathrm{B}, \mathrm{C})$ demonstrate that students internalized the learning outcomes and that they could reflect their subjective preferences. Within this context, Innci (2012) mentions that students who have experience for three-dimensional work also gain self-confidence development. In addition, the rich variety of the learning outcomes achieved with these activities shows similarities to Çapar's remarks about positive reflections of enriched presentations in student work and also to his results that more three-dimensional work should be included in the curricula (2006).

A significant finding of the research is the cognitive outcomes achieved by the students with the codes as alignment of idea and image (A, C) and knowledge on dimensioning $(\mathrm{B}, \mathrm{C})$ on the theme realization. Besides these codes, the $75 \%$ positive answers for the item "My friend implements art elements and design principles in her work" (i.4) at PEF applied at A, B and C schools concurrently demonstrates that artistic elements and principles are used suitably. Inci (2012) mentions that in the Visual Arts Curriculum there is not sufficient allocation for three-dimensional work and time is not sufficient, either. The results of this study also support Inci's (2012) view in his study when he states that three-dimensional works are of high educational value, which help students perceive depth, height, and width.

A significant difficulty in the study related to meet the learning outcomes is the insufficient class time that came about in two schools (B, C). Teachers from three schools (A, B, C) made various suggestions about how to improve three-dimensional work in classroom environment. In their studies Şişci (2016) ve İnci (2012) emphasized the inadequacy of the studio environment and advocated the view that a special studio for visual arts classes in each school would positively impact three-dimensional work by the teachers. Similarly, Çapar (2008) relates the issue of most subject teachers' training towards two-dimensional work with the lack of necessary requirements for implementation of three-dimensional work. On the other hand, it is attention-grabbing that the 
teachers of the three schools with no studios (A, B, C) participating in this study have views focusing on the fact that with these comprehensive activities learning outcomes, skills and values can be achieved ((MM), (AS), (TE) teacher SSIF, q.1). The teachers suggested being prepared for materials use, being planned for the scope of the activity, making selections suitable for classroom environment and also stated that museums could be used besides studios ((MM), (AS), (TE) teacher SSIF, q.11).

\subsection{Skills}

This research has been conducted through three-dimensional work and 56 from 153 codes of the data obtained are skills-based, which is a significant part. The volume of the obtained findings within the total of the findings demonstrates that students transferred the skills they acquired into behavior. A certain part of these are cognitive, academic and psychomotor skills, however, a part is communication skills and skills related to personal development. According to these results, skills and qualifications expected from instructional processes reach the target in classroom environment, where students play an active role in instruction.

Planning the relevant learning outcomes with correct skills is valuable in terms of effective education. Students carry out the three-dimensional work safely in classroom environment without memory work and learn through developing their skills. In order for them to enjoy the activities and have productive time by learning, some skills to realize the three-dimensional art work in the planned activities in this research have been attached priorities. For example, with the learning outcome "G.6.1.7. The student uses carving, assemblage or modeling techniques to form three-dimensional work." students are expected to gain Mathematical Qualification and Essential Qualifications in Science/Technology. This qualification develops mathematical thinking approach to solve a series of problems in daily life and develops the application of this skill. With the comprehensive activities that were planned students felt themselves creative $(A)$, had different thinking experiences $(C)$, enjoyed the abstraction process $(\mathrm{C}, \mathrm{B})$, objectified the mental image $(\mathrm{A})$, selected material suitable for the structure $(\mathrm{A})$ and the dimension (B), had personal solution-focused initiatives (A). Within this context, the participant teachers drew attention to the significance of the learning material (A, B) that was commonly prepared in a comprehensive way.

The visual arts course aims at developing student attitudes for critical appreciation and curiosity, interest in ethical problems, respect for safety and sustainability, valuing global scientific and technological developments particularly for him/herself, his/her family and the society. Moving from the topic of Anatolian Civilizations, a part of the content of social Studies course, the activity "My Money" has been prepared for this skill. This activity contributed to the students' skills of recognizing Anatolian Civilizations, reinforcing their knowledge, experiencing the interdisciplinary structure of the content cognitively and providing sustainability of culture. In addition, as the activity was realized with the relief technique as three-dimensional work, it also helped students to develop their mathematical skills. The connections between the art areas at the schools that came about commonly at schools were art essential area learning outcome (A, B), connections through art transmission of psychomotor skills (A, C); however, they were also beneficial in terms of life and career skill $(\mathrm{B}, \mathrm{C})$ and application of personal skills (A, C). Demir (2009) similarly emphasizes the fact that art critique work and three-dimensional works improve students' visual perceptions and psychomotor skills and also contribute to their critical thinking skills. Studies that show similarities to these results emphasize the role and significance of touching in literature frequently (Manners, 1997). Finally, it has been observed that in conditions with no studios similar to these three schools students take personal safety measures (A, C) for providing safe ((AS), (TE) SSCOF, i.2). Realization of three-dimensional work with such comprehensive activities is a strong indicator that demonstrates that at schools with no studios the expected skills develop and can develop with correctly planned three-dimensional applications in classroom environment.

While the activities were being planned, it was aimed that students gained Qualification related to Social and Citizenship with the title for the learning outcome "G.7.1.7. The student carries out three-dimensional work using waste material.". This qualification involves personal, interpersonal, cultural and intercultural competence and also being equipped with all forms of behavior for individuals to participate in social and working life effectively and constructively. It also involves the acquisition of various behavior to provide solving conflicts whenever necessary. Many of the codes that came into view during the research process bring clarity to this context. The codes that came into view commonly at the host schools, namely observing differences in perspectives $(\mathrm{A}, \mathrm{B}, \mathrm{C})$ transfer from daily life that attempts to provide association of art and life (A, B, C) put forth the feeling of creating together $(\mathrm{A}, \mathrm{C})$ for students, who are in a personal developmental stage. It also shows that social skills such as respecting different opinions $(\mathrm{C})$, getting to know one's own culture (A), acquisition of social values.

It was aimed that students gained Digital Qualification with the learning outcome "G.8.1.8. The student carries out three-dimensional work using different techniques and materials together." It involves the use information society 
technologies safely and critically for daily life and for communication. The said qualification is supported with basic skills such as accessing information within information technology and evaluating information, using computers for access and evaluation, preserving, producing, presenting and exchanging knowledge, also participation in networks through the internet and establishing communication. Particularly when the activity talking emojis was implemented at schools, it brought into view commonalities in terms of developing multi-competences (A, B), contribution of dimensioned work to skills (B, C), besides, it also provided opportunities to observe competences such as transmitting previous experiences $(\mathrm{A}, \mathrm{B}, \mathrm{C})$ and converting digital skills into products (A). The fact that the digital environments the students are intensively in could be moved to the applications with such comprehensive activities also aligns with İnci's (2012) results of the study, in which he evaluates the development of self-confidence with three-dimensional work used within the scope of the visual arts course according to student comments. These results reinforced the result that activities planned with multi-facets are effective on students. The activities planned with easily accessible materials for students as Karatop (2005) mentions in his study attract students' attention. Due to the nature of the structure of three-dimensional work, it is different from painting materials, however, when waste materials and cardboard that students can easily find are used for the purpose, they create the same three-dimensional work effect. Within the scope of the research, material variety has been taken into consideration as Karatop (2005) also states. According to the results of the research, it might be suggested that material variety is allocated a particular place, particularly at schools with no studios, in order to provide the learning outcomes and skills and values at necessary levels. Çapar (2012) states; "In spite of all these negative effects, with the committed efforts of enthusiastic teachers, materials such as paper-maché, wire, waste material can be used and opportunities for students to carry out three-dimensional work can be provided, be it to a small extent." Visual Arts teachers prefer paperwork that can be accessed easily in classroom environment and that can be easily shaped. In his study, Gökaydın (1998) reminds us that a sheet of paper used in a dimensional way creates the desire to shape it and can have it gain an artistic image and three-dimensionality. Moving from this view, it makes us consider that transferring this multi-faceted characteristic of paper, material variety, functional changes of materials would increase variety in student work. The remarks of teachers and students that place significance of material selection suitable, the environment, dimensioning and level, and particularly a remark of a student that comments on the enthusiasm for working with waste material as the abstract sculpture activity suggests "...making instead of throwing away" (C), demonstrates that solution-oriented progress is possible with constructive initiatives. These results show similarities to Çapar's (2012) views as well. Akınc1 (2009), emphasized that the significance of materials variety should be taken into consideration and for the planned activities easily accessible materials for students should be preferred in his study.

\subsection{Values}

The scope of instruction is to provide positive changes in student behavior, who will take their places in social life. Within the scope of this research, four basic values in alignment with learning outcomes and skills have been approached at the activities implicitly. Within the scope of this study, at the learning outcome "G.6.1.7. The student uses carving, assemblage or modeling techniques to form three-dimensional work." The value "Respect" has been approached and it was aimed that students get to know other cultures, too, and respect these cultures. At the learning outcome "G.7.1.7. The student carries out three-dimensional work using waste material." the students have been reminded with the value "Care and Responsibility" while the waste material was converted into art objects to improve their sensitivity on the issue of environmental pollution, which is an important of the current century and they were also reminded that they are responsible of their environment. At the learning outcome "G.8.1.8. The student carries out three-dimensional work using different techniques and materials together." the value "Inquiry" was implemented relating it to activities. Inquiry has provided that an $8^{\text {th }}$ grade student approaches topic such as critique, self-criticism and enquires about herself and her environment with the activity emojis. Within the scope of this research, values, which are a significant topic for societies to live together, are approached within the scope of the visual arts course under three-dimensional work and their significance in raising sound individuals. As a result of the research, it has come into view that many values were gained commonly. Students gained the following through the activities: Peer awareness (A, B); providing anti-consumption material (A, B, C); personalizing (A, B); developing self-confidence (A, B); developing artistic sensitivity (A, C); solving problems encountered at the implementation $(\mathrm{A}, \mathrm{B}, \mathrm{C})$; art production as recycling $(\mathrm{A}, \mathrm{B})$; expressing sensitivity through art $(\mathrm{B}, \mathrm{C})$ "Care and Responsibility" "Respect", "Inquiry" values. These results of the study demonstrate that it is in line with the Visual Arts Course Curriculum (MEB, 2017, p. 11) emphasizing the fact that values are acquired during the instructional process and transferred to new generations through three-dimensional work at schools without studios. The aim of values education is to raise individuals who recognize and adopt national, moral, and global values and changes these values into behavior internalizing them and this aim has been approached in all curricula. The Visual Arts Course Curriculum has specified 10 essential values and in the research selection of 
these values as appropriate for the activities has been left to the initiatives of the teachers according to their conditions. While preparing such comprehensive activities, each essential value should be specified taking into consideration its alignment with the relevant learning outcome and skill.

\subsection{Job Safety}

As per its nature, the visual arts course requires working with different materials and tools and thus, job safety factors have additional significance for this course. During this research it has been observed that when the activities are planned and implemented to cover job safety elements besides the educational factors of learning outcomes, skills and values, the likely negativities can be avoided. ((AS), (MM), (TE) SSCOF, i.1,2,6). According to the results of the research, it could be pointed out that at the implementation stage of these multi-faceted activities at all three schools the students used the materials safely and environmental safety was provided ((100\%), PEF, i.8; (65\%), SEF, i.15). Additionally, at A and C schools, when students felt a need for safety, they took their own safety measures ((58\%), PEF, i.8). At the beginning of each academic year teachers should explain job safety factors to the students while introducing course materials and should also oversee them. Sample cases for this situation are the remarks and initiatives of teachers at $\mathrm{B}$ and $\mathrm{C}$ schools on the safe management of the process (B, C) ((AS) SSCOF, i.8; (TE) SSCOF, i.6) and the above aligns with these remarks. Planning of the pre-implementation preparations at schools with no studios could be explained with the codes presentation of dimensioning stages (A), selection of materials appropriates for the level (A), safe management of the process (B, C), and safety elements (A, B). Within this context, it is also a significant finding that at the schools, teachers predict problems (A). While the school prepares students for life and teaches them to take precautions against such situations and to use these tools without harming themselves, job safety factors should also be taken into consideration and should be made part of school life. Tools, equipment, and materials should be used safely and various health problems of students (allergy, asthma, bronchitis etc.) should be known and taken notice of. (MEB, 2017). Students should be given information when materials and course equipment are used. Studio rules to be prepared for the course could be put up at a location that students can see, and negative situations could be avoided.

\section{References}

Akınc1, G. (2009). In art lesson curriculum, performed in high school establishments, the practice techniques, material varieties and effectiveness of the three-dimensional activities subject are examined in terms of teachers' and students' opinions. Unpublished master dissertation. Karadeniz Technic University. Institute of Social Sciences. Retrieved from https://tez.yok.gov.tr/UlusalTezMerkezi/TezGoster?key=CwVIqqBuz1VkysVpueogAeYb2VYgjM8qg_keu pgaIn8L0Doh3VAhTWqW0NcXtzYK

Arnheim, R. (1969). Visual thinking. USA: University of California Press.

Barnes, R. (1993). Art, design and topic work (pp. 8-13). London and New York: Routledge.

Canikoğlu, G. (2016). The views of secondary school visual arts teachers on the application of 'Visual Communication and Formatting' methods on the visual arts learning program. Unpublished master dissertation. Ankara Gazi University. Institute of Educational Sciences. Retrieved from https://tez.yok.gov.tr/UlusalTezMerkezi/tezDetay.jsp?id=p0-QnkC1MR4heDLs0kXv1w\&no=vl_q6Zc-sOO _geNJrkDuJg

Çapar, M. (2006). The effect of three-dimensional works of children between 9-12 on creativity education in basic education. Unpublished doctoral dissertation. Ankara Gazi University. Institute of Educational Sciences. Retrieved

from https://tez.yok.gov.tr/UlusalTezMerkezi/TezGoster?key=-L8ilcwn9ZRRc_YMKxXW1iPOyrd6V5rfG6dnk E7PN_Cxc90DoVYTWKJudMvANmxH

Çapar, M. (2008). Ilköğretim ikinci kademe görsel sanatlar eğitimi dersinde üç boyutlu çalışmaların önemi. Çukurova University Faculty of Education Journal, 3(35), 114-124. Retrieved from http://www.acarindex.com/dosyalar/makale/acarindex-1423874897.pdf

Chapman, H. L. (1994). A world of images. Worcester, Massachusetts USA: Davis Publications, Inc.

Creswell, J. W. (2013). Nitel araştırma yöntemleri: Beş Yaklaşıma Göre Nitel Araştırma ve Araştırma Deseni (Trans. M. Soydemir, S. B. Demir). Ankara: Siyasal Press.

Demir, C. (2009). The effect of arts criticism method on students? learning processes in three-dimensional works in visual arts course (a case from 8th grade classes). Unpublished doctoral dissertation. Ankara Gazi University. Institute of Educational Sciences. Retrieved from 
https://tez.yok.gov.tr/UlusalTezMerkezi/TezGoster?key=UPP_Zu9isEmWGFXFCBYasQMD6DZ1ahngKB boY4dRET5sa85dUDR4kSfonrCykciX

Demircioğlu, İ., \& Tokdemir, M. (2008). The role of history education in the process of construcing values: Aims, functions and content. Journal of Values Education, 6(15), 69-88. Retrieved from https://dergipark.org.tr/tr/pub/ded/issue/29185/312508

Efland, A. D. (2002). Art and cognition. New York: Teachers Collage Press.

EQF. (2017). European Qualifications Framework. The Counc1l of the European Union. Retrieved from https://eur-lex.europa.eu/legal-content/EN/TXT/HTML/?uri=CELEX:32017H0615(01)\&from=EN

Gel, H. Y. (1993). Bireyin gelişim süreci için en etkili yol "sanat eğitimi” ve çalışma alanları. Sanat Yazıları V. Ankara: Hacettepe University Faculty of Fine Arts Publishing: 13. Retrieved from http://sanatyazilari.hacettepe.edu.tr/img/1155381752019_3977602720.pdf

Gençaydın, Z. (1990). Sanat eğitiminin düşünsel temelleri, ortä̈ğretim kurumlarında resim-iş öğretimi ve sorunları. Ankara: TED Press.

Glesne, C. (2012). Nitel araştırmaya giriş (Trans. Eds. A. Ersoy \& P. Yalçınoğlu). Ankara: Anı Publishing.

Gökaydın, N. (1998). Eğitimde tasarım ve görsel algı. Ankara: The Ministry of National Education Publications: 3021.

Gökaydın, N. (2002). Temel sanat eğitimi. Ankara: MEB Press.

İnan, Ş. (2018). MEB (The ministry of national education) secondary education visual arts course workshop equipments and a workshop. Unpublished master dissertation. Ondokuz Mayıs University. Institute of Educational Sciences. Retrieved from https://tez.yok.gov.tr/UlusalTezMerkezi/tezDetay.jsp?id=Uo-K343Bw78mIfJn1wkYTA\&no=Nc_8ChB6G TQB7DGYPU16mA

İnci, H. (2012). Primary education, visual arts lesson, three-dimensional markup studies, stage in the objective reality of the students contribution to development of self-confidence. Unpublished master dissertation. Ondokuz Mayis University. Institute of Educational Sciences. Retrieved from https://tez.yok.gov.tr/UlusalTezMerkezi/TezGoster?key=1zw6GvYMe-q3Hf6HR-3USwlHckAGjzsJ0Vmis CZC0O8_Daf0f4CsgmSB4hMXi_gh

Karagöl, R. (2016). The contribution of the works which will be done with the wasted objects on teaching 3-dimension designs on visual art lessons (6th grade instance). Unpublished master dissertation. Gazi University. Institute of Educational Sciences. Retrieved from https://tez.yok.gov.tr/UlusalTezMerkezi/tezDetay.jsp?id=vGgwmDMzgvyrkC4JE7pcsA\&no=yOorTRTW7 Z5YEvVHEVQEow

Karaoğlu, S. (2004). Ressamlar Türk ve dünya ressamlart-2. İstanbul: Nesa Press.

Karatop, F. (2005). The concept of three dimension in sixth grade art lessons of primary school. Unpublished master dissertation. Marmara University. Institute of Educational Sciences. Retrieved from https://tez.yok.gov.tr/UlusalTezMerkezi/TezGoster?key=-L8ilcwn9ZRRc_YMKxXW1mexftdgdio9siUxG_ nXyQRXsynTfGIjlzdPnf75iJyv

Kenavlı S. (2017). Investigations on the opinions of the visual arts workshop of educational teachers of the secondary school of visual arts. Unpublished master dissertation. Marmara University. Institute of Educational Sciences. Retrieved from https://tez.yok.gov.tr/UlusalTezMerkezi/tezDetay.jsp?id=oLrOmS1MgdRe_8E318-Kdg\&no=qmEYct8osU3 MswMhGJImAQ

Küpeli, A. E. (2014). Implication of the method of multifield art education in three dimensions design works of students within the scope of basic design lessons. Unpublished master dissertation. Ankara Gazi University. Institute of Educational Sciences. https://tez.yok.gov.tr/UlusalTezMerkezi/TezGoster?key=gyLHMouPes-CvnhRcjQsKbxMzQmQoKp6fZ2u g3ah4mha1DfYdphesWKA48U1v-HG

Lancaster, J. (2002). Art in the primary school. Routledge. https://doi.org/10.4324/9780203407035

Manners, N. (1995). Three-dimensional experience. Hodder and Stoughton: London.

May, W. T. (1987). Student responses to media: Implications for elementary art curriculum. Studies in Art 
Education: A Journal of Issues and Research, 28(2), 105-107. https://doi.org/10.2307/1320787

MEB. (2017). Görsel Sanatlar Dersi (1-8.) Sinıflar Öğretim Programı ve Kılavuzu, Ankara: Milli Eğitim Bakanlığ1 $\quad$ Press. Retrieved from http://mufredat.meb.gov.tr/Dosyalar/2018121111026326-GORSEL\%20SANATLAR.pdf

Merriam, S. B. (2018). Nitel Araştırma Desen ve Uygulama İ̧̧in Bir Rehber (3rd ed., Trans Ed. Selahattin Turan). Ankara: Nobel Publishing.

Miles, M. B., \& Huberman, A. M. (2019). Anlamlandırmak: Sonuç çıkarmak ve doğrulamak. In S. A. Altun \& A. Ersoy (Eds.), Genişletilmiş bir kaynak kitap: Nitel veri analizi (3rd ed., Trans. H. Ç. Yıldırım \& S. Akayoğlu, Chap. 10, pp. 245-287). Ankara: Pegem Academy Publishing.

Özdemir, Ç. (2009). The act of about three dimensional aplications to student creativity in visual art lessons at the level of I. primary. Unpublished master dissertation. Gazi University. Institute of Educational Sciences. Retrieved

from https://tez.yok.gov.tr/UlusalTezMerkezi/tezDetay.jsp?id=Emz64dyiYsem17Sbvew4gg\&no=20h5dPyJwXd 07 oOfMcqB1w

Patton, M. Q. (2018). Nitel araştırmaların desenlenmesi. In M. Bütün \& S. B. Demir (Eds.), Nitel araştırma ve değerlendirme yöntemleri (Trans. Eds. İ. Eti \& B. Turhan Türkkan, pp. 209-258). Ankara: Pegem Publishing.

San, İ. (2003). Sanat eğitimi kuramları (2nd ed.). Ankara: Utopya Publishing.

Sayg, S.. (2015). A practice study concerning three-dimensional plastic (Ceramic clay) application in a secondary school 5th grades visual arts lesson. Unpublished master dissertation. Anadolu University. Institute of Educational Sciences. Retrieved from https://tez.yok.gov.tr/UlusalTezMerkezi/tezDetay.jsp?id=mQ19bqQzbaT-po27_vab-A\&no=ZfJx8CCzd2Lh vIJXDCacUg

Sharples, D. E. (1985). Three-dimensional work in the primary school. Journal of Art \& Design Education, 4(1), 53-60. https://doi.org/10.1111/j.1476-8070.1985.tb00144.x

Şişci F. (2016). The effect of article on student application process in three dimensional studies. Unpublished master dissertation. Abant İzzet Baysal University. Institute of Educational Sciences. Retrieved from https://tez.yok.gov.tr/UlusalTezMerkezi/TezGoster?key=OykDDeWBWTL9-Wm52sZBrCUAOt_Nt960pE 1DomZjFjerHnUaheB1-Y8072qrJ8Ss

Stake, R. E. (1995). The art of case study research. Thounsand Oaks, CA: Sage.

Thistlewood, D. (Ed.). (1991). Critical studies in art and design education. Heinemann Educational Books Inc., 361 Hanover St., Portsmouth, NH 03801-3959.

TQF. (2015). Turkish Qualifications Framework [Türkiye Yeterlilikler Çerçevesi]. Mesleki Yeterlilik Kurumu. Retrieved from https://tyc.gov.tr/yayinlar_dokumanlar?kategoriId=3a44289d-519a-4745-b9fd-2e27da2813ad\&search=

Yıldırım, A., \& Şimşek, H. (2013). Sosyal bilimlerde nitel araştırma yöntemleri. Ankara: Seçkin Publishing.

Yin, R. K. (2009). Case study research: Design and method (4th ed.) Thousand Oaks, CA: Sage.

\section{Note}

The present study is a summarised form of the Master's thesis, 'Three-dimension applications planned according to secondary level visual art instruction program and to practice in classroom: A case study', which was completed by Mert Ünlüsoy in 2019, under the supervision of Berna Coşkun Onan (PhD) at Bursa Uludag University, Fine Arts Department in Faculty of Education. This thesis and concerning forms can be examined fully

https://tez.yok.gov.tr/UlusalTezMerkezi/TezGoster?key=aEzj_IdWAsjiSAfK3qwrBqtY8LRdWEE0e_AErD0Irs wDpeB0_LuFX75RDiilKNIN

\section{Copyrights}

Copyright for this article is retained by the author, with first publication rights granted to the journal.

This is an open-access article distributed under the terms and conditions of the Creative Commons Attribution license (http://creativecommons.org/licenses/by/4.0/). 